\title{
MENGULIK KOMPLEKSITAS PROSES DIFUSI INOVASI TEKNOLOGI DI PERPUSTAKAAN
}

\author{
Endang Fatmawati
}

\begin{abstract}
Innovation is a certain idea, practice or product that is realized and accepted as something new to be adopted. Adoption is a process from getting acquainted with an innovation to decide to accept or reject. There is an innovation category that is sustaining and discontinues. An indication that there has been an innovation acceptance process is that it appears in behavioral, cognitive, affective and psychomotor changes.
\end{abstract}

Keywords: adoption, innovation, diffusion, library, technology.

\section{PENDAHULUAN}

Saat ini harus disadari bahwa dengan menggunakan media teknologi, maka pekerjaan dapat dilakukan lebih mudah. Apalagi era revolusi industri 4.0 saat ini, telah menggiring masyarakat luas untuk mengenal inovasi teknologi dan juga perkembangannya yang begitu masif. Perpustakaan menjadi bidang yang ikut terkena imbasnya, mengingat pemustaka yang dilayani sudah semakin lekat dengan teknologi digital.

Dalam konteks perpustakaan, kemajuan dalam mengadopsi teknologi menjadi angin segar dan memberikan warna baru. Geliat untuk bertransformasi bagi perpustakaan di era industri 4.0 menunjukkan indikasi yang konstruktif untuk menuju perpustakaan 4.0. Jika perpustakaan tinggal diam maka perpustakaan menjadi tidak menarik di mata pemustakanya. Tuntutan generasi pemustaka digital natives menjadi salah satu faktor yang berpengaruh bagi pihak pengelola perpustakaan untuk mengadopsi inovasi teknologi. Harapannya adalah mampu mengakomodir kebutuhannya, walaupun fenomena penggunaan teknologi di perpustakaan dalam kaitannya dengan konsep difusi inovasi belum optimal.

Untuk menuju pada adopsi inovasi teknologi, maka membutuhkan suatu persiapan di awal yang matang dan terencana dengan baik. Salah satunya adalah kesiapan dari segi kompetensi internal pustakawannya sebagai prioritas.
Inovasi tidak hanya berkaitan dengan teknologi, namun bisa produk maupun yang lainnya. Artikel ini sebagai pengantar untuk memberikan pemahaman konseptual terkait kompleksitas proses difusi inovasi teknologi di perpustakaan.

\section{PEMBAHASAN}

Dari pengertiannya, kata "mengulik" merupakan kata kerja yang artinya mengusut atau menyelidiki. Jika melihat sejarah munculnya teori difusi inovasi, bahwa teori difusi inovasi sebetulnya dimulai pada awal abad ke20 (tahun 1903), ketika Gabriel Tarde (sosiolog Perancis) mulai memperkenalkan "Kurva Difusi" berbentuk huruf $S$ (S-shaped Diffusion Curve).

Pada kurve tersebut ada dua sumbu, yaitu tingkat adopsi dan dimensi waktu. Dalam perkembangannya, kemudian bermunculan para tokoh teori difusi inovasi, seperti halnya pada tahun 1961, muncul tokoh Everett M. Rogers (Professor dan Ketua Departemen Komunikasi dan Jurnalisme di Universitas New Mexico), dengan karya besarnya yang berjudul Diffusion of Innovation.

Sebelum membahas tentang inovasi teknologi, kita sering mendengar kata "difusi" dan "adopsi" dalam keseharian. Perbedaan keduanya bahwa adopsi yaitu proses difusi yang terjadi antar individu, sedangkan

\footnotetext{
* Pustakawan Perpustakaan Universitas Diponegoro

E-mail: endangfatmawati@undip.ac.id
} 
adopsi yaitu proses yang terjadi di dalam individu masing-masing. Dalam penggunaannya terkadang kita tanpa sadar sering terbalik-balik.

Pada saat memulai proses adopsi, berarti akan melalui tahapan-tahapan dan dimulai dari mulai mengenal suatu inovasi sampai dengan ketika memutuskan untuk menerima atau menolak inovasi tersebut. Selanjutnya ketika sudah masuk dalam tahap penerimaan teknologi, maka maksud dari penerimaan inovasi adalah bukan sekedar tahu saja, tetapi harus mampu menerapkannya dengan benar sesuai kapasitas perpustakaannya.

Dengan demikian, adopsi juga bukan sekedar adaptasi saja, tetapi lebih pada proses yang berlangsung alami untuk melakukan penyesuaian terhadap kondisi yang saat itu ada di perpustakaan. Tahapan-tahapan dalam proses adopsi menurut Mundy (2000) yaitu: kesadaran (awareness), perhatian (interest), penaksiran (evaluation), percobaan (trial), adopsi (adoption), serta konfirmasi (confirmation). Jika dibumikan dalam tataran yang dilakukan oleh pustakawan sampai dengan tahap penolakan, dapat saya jelaskan sebagai berikut:

1. Tahap kesadaran, yaitu ketika pustakawan menyadari bahwa inovasi teknologi yang ditawarkan, dapat membuat kualitas layanan perpustakaan menjadi lebih baik.

2. Tahap perhatian, yaitu ketika pustakawan mulai tertarik terhadap inovasi teknologi yang akan diterapkan kemudian berusaha mencari informasi yang relevan dengan teknologi yang dimaksud.

3. Tahap penaksiran, yaitu ketika pustakawan mulai menimbang dan memikirkan apakah inovasi teknologi mampu dilakukan dengan tenaga dan sumber daya yang dimiliki oleh perpustakaan.

4. Tahap percobaan, yaitu ketika pustakawan mulai berinisiatif untuk mencoba dengan menerapkan inovasi teknologi pada lingkup kecil dahulu, kemudian jika berhasil akan dilanjutkan untuk mengadopsi, tetapi kebalikannya jika gagal maka akan memberikan penolakan.

5. Tahap konfirmasi, yaitu ketika pustakawan mengadopsi inovasi teknologi, kemudian pustakawan meminta konfirmasi kepada rekan kerjanya tentang apa yang dialami dan telah dilakukan.

6. Tahap penolakan, yaitu ketika pustakawan mengalami hambatan atau mengalami kegagalan selama memasuki tahapan sebelumnya (yaitu: mencoba dan konfirmasi), sehingga pustakawan memutuskan untuk tidak mengadopsi inovasi teknologi yang ditawarkan.
Ada perbedaan konseptual antara "difusi inovasi" dan "adopsi inovasi". Perbedaannya bahwa jika proses difusi inovasi berarti pembawa inovasinya berasal dari "dalam" sistem perpustakaan itu sendiri. Sementara itu, jika proses adopsi inovasi berarti pembawa inovasinya berasal dari "luar" sistem perpustakaan yang menjadi target sasaran.

Secara umum, difusi merupakan proses pada saat suatu inovasi disampaikan atau dikomunikasikan melalui saluran tertentu, sehingga yang disampaikan pesannya adalah berupa ide baru. Untuk mewujudkannya membutuhkan sarana sebagai penggerak difusi, baik itu melalui aktivitas pemrakarsa, penggagas ide, maupun motivator. Aspek ini penting sebagai fasilitator untuk menghantarkan pustakawan di perpustakaan lain dalam menerapkan inovasi.

Perlu diperhatikan dengan detail bahwa inovasi bisa berhubungan dengan tingkat keaslian dari inovasi itu sendiri. Proses inovasi yang sedang berjalan di sebuah perpustakaan harus diyakini di awal untuk kemajuan, baik dari strategi menyelesaikan masalah maupun meningkatkan kinerja. Oleh karena itu, siapa (who) yang menginisiasi atau yang memprakarsai hadirnya inovasi teknologi pada sebuah perpustakaan menjadi aspek utama yang perlu diperhatikan.

Kekhawatiran dampak negatif dari mengadopsi sesuatu yang baru memang wajar. Hal ini justru menunjukkan adanya keseriusan dalam proses adopsinya. Keinovatifan dalam merespons pesatnya perkembangan teknologi menjadi dasar untuk melakukan proses adopsi. Inovasi teknologi dalam ranah perpustakaan merupakan sesuatu yang kompleks. Saya katakan kompleks karena permasalahan yang perlu diselesaikan ada banyak aspek. Apalagi di setiap jenis perpustakaan, dipastikan akan berbeda permasalahannya.

Katakan untuk urusan adopsi sistem RFID. Ide yang ada dalam sistem RFID sungguh sangat bagus, namun komponen lain juga ikut berperan, seperti kesiapan SDM, anggaran, dan sumber daya lainnya yang terkait dengan pelaksanaannya. Selanjutnya persoalannya apakah inovasi adalah sesuatu yang baru sama sekali atau tidak? Menurut pendapat saya, jawabannya adalah tidak.

Alasannya karena pada dasarnya kebaruan inovasi itu diukur secara subjektif menurut pandangan setiap individu pustakawan yang menerimanya. Artinya jika suatu ide dianggap baru oleh seorang Pustakawan X maka menjadi inovasi bagi Pustakawan X tersebut. Dalam tataran ini, berarti kebaruan subjektif yang dimaksud bagi seseorang akan menentukan reaksinya terhadap inovasi tersebut. 
Inovasi pustakawan merupakan ide atau gagasan maupun tindakan tertentu yang dianggap oleh pustakawan sebagai sesuatu yang baru. Pada era disrupsi teknologi yang saat ini secara umum menjadi topik pembicaraan serius, inovasi dikaitkan dengan kebaharuan di bidang teknologi. Esensi dari proses difusi adalah adanya proses pertukaran informasi dari seseorang ke orang lain. Praktiknya ketika seorang pustakawan mengomunikasikan suatu ide baru ke orang lain. Dimensi dari konsep difusi inovasi, terdiri dari:

1. Pengetahuan, yaitu proses mengenali dan memahami inovasi. Indikator pengetahuan meliputi pengetahuan yang dimiliki pustakawan terkait dengan konsep, manfaat, mekanisme, maupun berbagai aspek yang berhubungan dengan inovasi yang akan diadopsi.

2. Persuasi, yaitu proses inisiasi untuk mengumpulkan informasi, konseptualisasi pembentukan sikap dalam diri untuk menyukai atau tidak menyukai inovasi. Indikatornya bisa diukur dari sikap pustakawan dalam mencari informasi terkait inovasi yang akan diadopsi melalui berbagai saluran komunikasi.

3. Pengambilan keputusan, yaitu keterlibatan individu dalam aktivitas yang mengarah pada pengambilan keputusan untuk mengadopsi atau menolak inovasi. Indikator pengambilan keputusan diketahui dari perilaku pustakawan saat memutuskan untuk menerima inovasi dan mengadopsinya maupun keputusan ketika menolaknya.

Kategori inovasi ada yang inovasi terusan (sustaining innovation) dan inovasi terputus (discontinues innovation). Terusan berarti proses inovasi yang diadopsi membawa perubahan baru tetapi tetap mendasarkan pada sistem yang sedang berjalan, misalnya konversi dari versi lama ke versi baru. Sebaliknya, jika terputus berarti proses adopsi inovasi yang diadopsi sama sekali baru atau dengan kata lain tidak berdasar pada sistem yang sudah ada sebelumnya. Hal ini misalnya ganti program atau software dengan sistem informasi baru yang lebih kredibel dan jauh lebih efisien.

Jadi dalam praktinya teknologi yang ada di perpustakaan bisa diganti dengan inovasi teknologi yang benar-benar baru atau tetap meneruskan teknologi lama yang sudah digunakan kemudian memperkuat dengan inovasi teknologi baru. Bagaimanapun inovasi menjadi sesuatu yang menantang untuk diwujudkan. Namun demikian, tidak semua inovasi langsung begitu saja diterapkan tanpa dianalisis terlebih dahulu.
Hal ini penting, karena setiap inovasi akan memiliki karakteristik atau atribut tersendiri. Perlu kiranya merencanakan dengan sebaik mungkin, memperhatikan sisi kemanfaatan, maupun dampak positif dari inovasi yang akan dilakukan.

Untuk karakter yang menandai setiap gagasan atau cara baru dalam penerimaan inovasi setiap individu ditandai dengan:

1. Keuntungan relatif (relative advantage), dengan melihat apakah suatu inovasi menurut seseorang dianggap lebih baik atau unggul dari yang pernah ada sebelumnya.

2. Keserasian atau kesesuaian (compatibility), dengan melihat apakah inovasi yang hendak didifusikan serasi dengan hal-hal yang ada sebelumnya, seperti: nilai, sistem kepercayaan, gagasan, kebutuhan, selera, dan lain sebagainya.

3. Kerumitan (complexity), dengan melihat apakah inovasinya sukar dipahami atau justru dikhawatirkan akan menambah beban.

4. Kemungkinan dapat diujicobakan (trialability), dengan melakukan uji coba terlebih dahulu agar terhindar dari risiko yang kemungkinan akan ditimbulkan.

5. Dapat dilihat atau mudah diamati (observability), dengan melihat bukti inovasi tersebut secara seksama sebagai bahan pertimbangan untuk menerima inovasi tersebut.

Kembali pada teori Rogers mengenai proses difusi, bahwa elemen utama dari proses difusi tersebut, mencakup unsur: inovasi, saluran komunikasi, kurun waktu, dan sistem sosial. Dalam inovasi ada komponen ide dan komponen objek sebagai produk fisik dari ide tersebut. Saluran komunikasi untuk menyalurkan informasi inovasi kepada masyarakat luas dengan mengacu pada tujuan dan jumlah sasaran yang ingin dicapai. Kurun waktu menunjukkan adanya proses waktu yang dibutuhkan untuk sampai pada mengadopsi inovasi. Sistem sosial diyakini akan memudahkan terjadinya adopsi inovasi karena melalui sistem sosial sebagai media agar inovasi dapat diterima oleh semua lapisan dalam masyarakat, meskipun kategori individu masyarakatnya sangat beragam.

Namun demikian, untuk sampai pada penerapan inovasi, perlu memahami dahulu karakteristik yang menerima inovasi teknologi. Penjabaran karakteristik calon pengadopsi inovasi, misalnya: tingkat pendidikan, 
latar belakang sosial budaya, kelas sosial, pengalaman bekerja di perpustakaan, usia, dan lain sebagainya. Bahkan kalau perlu dalam prosesnya juga perlu ditambahkan kegiatan sosialisasi, pameran, berdiskusi bersama, maupun pengarahan. Upaya ini dimungkinkan untuk dilakukan agar ada kesamaan persepsi terhadap inovasi teknologi yang akan diadopsi.

Meminjam apa yang dikemukakan oleh Rogers (2003: 22) tentang kategori pengguna inovasi, maka dapat saya jelaskan sebagai berikut:

1. Inovator (Innovator), merupakan pustakawan yang berani dan siap mencoba hal yang baru. Pada kategori inovator ini, hubungan sosial mereka cenderung lebih erat dibanding dengan kelompok sosial lainnya, sehingga kelompok pustakawan inovator lebih dapat membentuk komunikasi yang baik meskipun terdapat jarak geografis.

2. Pengguna awal (early adopter), merupakan pustakawan yang menghasilkan "opinion leadership" yang tinggi dan selalu mencari informasi tentang inovasi teknologi yang menjadi tren untuk pengembangan perpustakaan.

3. Mayoritas awal (early majority), merupakan pustakawan yang membutuhkan waktu lebih lama dari kelompok sebelumnya. Pertimbangan yang ada karena lebih hati-hati sebelum membuat keputusan dalam mengadopsi inovasi teknologi. Pustakawan yang tergolong sebagai adopter mayoritas awal akan menjalankan fungsi penting dalam melegitimasi inovasi dan menunjukkan bahwa sebuah inovasi layak digunakan atau bermanfaat.

4. Mayoritas akhir (late majority), merupakan pustakawan yang cenderung ragu-ragu dalam mengadopsi dan menunggu hingga kebanyakan orang telah mencoba dan mengadopsi inovasi sebelum pustakawan mengambil keputusan.

5. Laggard, merupakan pustakawan yang terakhir melakukan adopsi inovasi. Kebalikan dari kelompok pengguna awal bahwa laggard merupakan kelompok penolak dan memiliki "opinion leadership" yang rendah, berusia tua, dan berpikiran konservatif. Kondisi yang demikian biasanya menyebabkan kelompok laggard biasanya menjadi yang paling akhir dalam menerima suatu inovasi.

Setiap pustakawan memiliki perbedaan dalam memahami inovasi teknologi. Respons yang sifatnya pro dan kontra menjadi hal yang biasa terjadi. Namun terasa indah dalam sebuah tim kerja jika bisa saling memahami adanya perbedaan pendapat dan saling menghargai. Suatu hal yang perlu diingat bahwa terkadang teman kerja kita akan melihat dunia di sekelilingnya dengan caranya sendiri yang unik dan berperilaku sesuai dengan interpretasi masing-masing.

Lalu bagaimana dengan sikap pimpinan di perpustakaan menghadapi kondisi yang demikian ?. Asumsi saya adanya sikap untuk memahami setiap interpretasi persepsi pustakawan, akan membantu seorang pimpinan menjelaskan hakikat perbedaan, sehingga dapat dipertimbangkan secara logis. Hal ini senada dengan yang dikemukakan oleh Ivancevich (2011: 116) bahwa setiap orang membuat pilihan pribadi dan merespons dengan cara yang berbeda.

Inovasi dikatakan menjadi sebuah penerapan pengetahuan baru ketika pustakawan mulai mengambil alih pengetahuan, maupun ide atau gagasan, praktik dan teknologi, lalu menerjemahkannya ke dalam perubahan yang membawa kebermanfaatan terhadap perpustakaan. Hanya saja sesuatu yang dianggap baru itu belum tentu sama diantara sesama pustakawan, bisa jadi baru menurut Pustakawan A di Perpustakaan X tetapi tidak baru menurut Pustakawan B di Perpustakaan Y.

Terlepas dari persoalan perbedaan, poin penting bahwa bagi perpustakaan yang sudah menerima inovasi teknologi, alangkah lebih baik juga melakukan komunikasi berkelanjutan dalam jejaring perpustakaan. Artinya setelah proses adopsi inovasi teknologi selesai dilakukan, maka langkah selanjutnya yang perlu adalah melakukan proses difusi inovasi, yang intinya menyebarkan pada orang lain maupun perpustakaan lain.

Proses difusi inovasi teknologi dilakukan agar ada pembaharuan dan perbaikan inovasi teknologi secara berkesinambungan dan menjadi semakin lebih baik. Jadi tidak hanya mengadopsi inovasi teknologi, lalu urusan selesai begitu saja. Namun perlu diperhatikan juga dalam proses pelaksanaannya, perlu mengidentifikasi kendala yang muncul, hambatan yang dihadapi, kelemahan, dan permasalahan lainnya di lapangan.

\section{PENUTUP}

Capaian bahwa inovasi teknologi telah benar-benar diadopsi di perpustakaan nampak ketika ada perubahan perilaku pustakawannya, baik dari sisi pengetahuan, sikap, dan keterampilan. Selanjutnya adopsi teknologi 
agar hasilnya maksimal maka membutuhkan proses komunikasi yang intens, mengambil keputusan yang berdasarkan percobaan, dan membutuhkan kesiapan baik pustakawan maupun sumber daya lainnya yang ada di setiap perpustakaan.

\section{DAFTAR PUSTAKA}

Ivancevich. 2011. Perilaku dan Manajemen Organisasi. Jakarta: Erlangga.

Mundy, Paul. 2000. Adopsi dan Adaptasi Teknologi Baru. Bogor: PAATP3.

Rogers, Everett. M. 2003. Diffusion of Innovations. $5^{\text {th }}$ edition. New York: Free Press. 